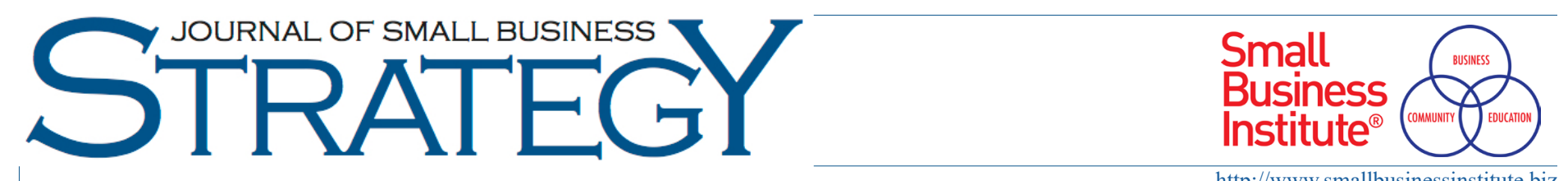

http://www.smallbusinessinstitute.biz

\title{
Family firm heterogeneity and tax aggressiveness: A quasi-experimental analysis of the impact of different family generations
}

\author{
José A. Clemente-Almendros ${ }^{1}$, Sergio Camisón-Haba, ${ }^{2}$, César Camisón-Zornoza, ${ }^{3}$ \\ ${ }^{1}$ Universidad Internacional de La Rioja, Facultad Empresa y Comunicación, Avenida de la Paz, 137, 26006 Logroño, La Rioja, Spain, jose- \\ antonio.clemente@unir.net \\ ${ }^{2}$ Universitat de València, Facultad de Economía, Departamento de Dirección de Empresas, Av. dels Tarongers, s/n, 46022 Valencia, Spain, \\ sergio.camison@uv.es \\ ${ }^{3}$ Universitat de València, Facultad de Economía, Departamento de Dirección de Empresas, Av. dels Tarongers, s/n, 46022 Valencia, Spain, \\ cesar.camison@uv.es
}

Keywords:

Tax aggressiveness, Thin capitalization rule, Leverage, Family firm, Generation

\section{A B S T R A C T}

This paper analyses tax aggressiveness in family firm generations. Moreover, taking into account the heterogeneity in family firms, we check whether the successive generations in control show different tax avoidance behaviour. The empirical evidence, based on the quasi-experiment of the 2012 Spanish thin capitalization rule, reveals that there is a positive relationship between tax aggressiveness and successive generations. Moreover, the founder and second generations follow a similar conservative tax avoidance approach, whereas the third and fourth generations are found to be more tax aggressive.

\section{Introduction}

Tax planning is critical for companies and has attracted growing interest from researchers, practitioners and policy-makers (Minnick \& Noga, 2010; Shackelford \& Shevlin, 2001). Taxes represent an important cost for the company since they result in a potential lower cashflow for the shareholders (Chen et al., 2010), and influence company long-term growth and investment (Sánchez et al., 2016). Tax avoidance, which is a specific form of tax planning that seeks to reduce the tax payments owing and thus increase net income (Frank, Lynch and Rego; 2009), has also captured the attention of researchers and public institutions (Desai \& Dharmapala, 2008; Hanlon \& Heitzman, 2010; OECD, 2013; OECD, 2015). In line with Chen et al. (2010), in our study, tax aggressiveness refers to "downgrade management of taxable income through tax planning activities". Alternatively, we could use the expression tax management. Following the suggestion of several authors to focus on the understudied area of family firm research (Mazzi, 2011; Sánchez et al., 2016; Steijvers \& Niskanen, 2014) our interest is in determining whether tax aggressive-

Journal of Small Business Strategy

2021, Vol. 31, No. 03, 102-121

ISSN: 1081-8510 (Print) 2380-1751 (Online)

CCopyright 2021 Small Business Institute ${ }^{\circledR}$ ness varies depending on the influence of different family generations, by analysing the effect of a reduction in interest deductibility on the capital structure of family firms.

Although business control and ownership structure are determinants of tax aggressiveness, this topic has not been widely explored (Hanlon \& Heitzman, 2010; Shackelford $\&$ Shevlin, 2001). Family firms differ from other companies in terms of specific intrinsic factors; they thus represent a unique framework within which to examine the influence of ownership structure on tax aggressiveness (Chen et al., 2010). Family control of the business is one important factor (Ferramosca \& Ghio, 2018), or more specifically, intergenerational transfer of family control (Anderson et al., 2003; Miller \& Le Breton-Miller, 2006). The importance of family control of the business relies on being part of the unique framework that family firms represent. It is a non-economic goals that, in view of SEW, affect family firm decisions (Gómez-Mejía et al., 2007) and sometimes against economic benefits (Gallo et al., 2004). Another differential is the importance of family reputation (Carcello et al., 2002; Gedajlovic \& Carney, 2010; Naldi et al., 2013).

There is a lack of empirical research about the level of active tax management or tax aggressiveness of family firms (Desai \& Dharmapala, 2006; Scholes et al., 2009); moreover, the literature reports contradictory results. Whereas

APA Citation Information: Clemente-Almendros, J. A., Camisón-Haba, S., \& Camisón-Zornoza, C. (2021). Family firm heterogeneity and tax aggressiveness: A quasi-experimental analysis of the impact of different family generations. Journal of Small Business Strategy, 31(3), 102121. 
there are studies showing a positive relationship between family firm status and tax aggressiveness (Gaaya et al., 2017; Koverman \& Wendt, 2019; López et al., 2019; Mafrolla \& D'Amico, 2016;), the opposite relationship has also been found (Bauweraerts \& Vandernoot, 2019; Brune et al., 2019; Chen et al., 2010; Sánchez et al., 2016; Steijvers \& Niskanen, 2014). In addition, while a large body of literature has focused on the comparison between family and non-family firms, private and public firms, or large and small private firms, few studies have analysed the extent to which the well-known heterogeneity of family firms (Brigham et al., 2019; Chua et al., 2012; Stanley et al., 2019) may affect their tax decisions and thus influence the differences in behaviour compared to non-family firms. Brune et al. (2019) found family involvement in firm management has a positive effect on active tax avoidance, compared to non-family firms. Kovermann and Wendt (2019) showed that tax avoidance is positively related to the percentage of family ownership. Sánchez et al. (2016) found that the first generation is less active in terms of tax avoidance than the second and subsequent generations, whereas the family ownership had a negative relationship with tax management. Bauweraerts and Vandernoot (2019) and Steijvers and Niskanen (2014) demonstrated that family firms with a lower CEO ownership share show greater tax aggressiveness.

Another interesting issue which is worth mentioning is that most of the related literature on tax avoidance is focused on public or large companies. More detailed research is needed on family-owned small and medium-sized enterprises (SMEs) due to their unique features. In family SMEs, certain specific traits take on special relevance, such as the greater importance of socioemotional issues (for instance, reputation) and the effects of family heterogeneity (for instance, family values, family generations, different management experience and professionalization). This results in a unique attitude towards tax decisions, a fact which becomes increasingly relevant with the presence of successive family generations (Sánchez et al, 2016). In addition to the above, there are certain specific influences. For instance, family SMEs are under less pressure from the financial markets and are less exposed to information asymmetries (Kovermann \& Wendt, 2019). The fact that they are under less pressure from financial markets may also positively affect their dividends policy (Michaely \& Roberts, 2012). Moreover, family SMEs often face the challenge of limited strategic planning (Zehrer \& Haslwanter, 2010). Finally, a better understanding of tax management attitudes in family firms can be gained by studying family SMEs as they are the predominant type of family firm (Sánchez et al., 2016; Steijvers \& Niskanen, 2014).

It is particularly noteworthy that the abovementioned branch of the literature has followed the same empirical strategy to study tax avoidance in family firms; namely the use of different measures of the effective tax rate (Manzon \& Plesko; 2002) as a variable for tax aggressiveness. Notwithstanding the sometimes contradictory empirical evidence (Fama, 2011), since Modigliani and Miller (1963) first proposed the tax advantages of financial debt for firm value, it has been accepted that corporate taxes have an effect on corporate indebtedness decisions (Feld et al., 2013). This advantage is due to the asymmetric tax treatment of equity and debt financing, since interest expenses from debt are deductible from the taxable income, reducing the tax liability. In order to address this asymmetry, governments have attempted to reduce or limit the abovementioned tax deduction by enforcing so-called thin capitalization rules (Dourado \& de la Feria, 2008; Gouthière, 2005). Thus, this reduction in the deductibility of interest expenses (which means an increase in the tax liability) leads to a decrease in debt ratios (Clemente \& Sogorb, 2016; Mardan, 2017; Overesch \& Wamser, 2010). In this context, companies that engage in tax planning, or are inclined towards tax aggressiveness, will lower their leverage ratios when they are affected by the thin capitalization rule.

The importance of the tourism industry worldwide (Mariz-Pérez, \& García-Álvarez, 2009; Su \& Lin, 2014), and in Spain in particular (Camisón et al., 2016; Vacas \& Landeta, 2009), is beyond doubt. Thus, the tourism industry needs access to more extensive knowledge about the factors affecting it (Andrew et al., 2007; Seguí et al., 2019); in particular, more research is needed regarding corporate governance factors in this industry (Al-Najjar, 2014; Chen et al., 2005), government fiscal policy changes (Chen et al., 2009), and specifically about firm ownership and control characteristics (Mazzi, 2011). As for family firms and the intergenerational transfer process, reputation plays a critical role (Gedajlovic \& Carney, 2010; Steijvers \& Niskanen, 2014). In the same vein, reputation is a key factor in the tourism industry (Camisón et al., 2016; Correia \& Kastenholz, 2011; Singal, 2015).

Accordingly, this paper aims to shed light on the effect of family firm heterogeneity, in terms of the controlling generation, on tax management in family SMEs. Analysing this factor can provide a better understanding of their managerial behaviour (Brune et al., 2019). More specifically, using a sample of 128 family SMEs in the Spanish tourism industry, we analyse whether the first and subsequent generations show different levels of tax aggressiveness. We expect that, in family SMEs affected by the 2012 fiscal reform, the founder and successive generations show different reductions in their levels of indebtedness.

This study contributes to the literature on the relation- 
ship between family firm heterogeneity and tax aggressiveness in family firms in several ways. First, we focus on tax aggressiveness in a family firm context taking into account the heterogeneous behaviour of the different generations in control (Chirico et al., 2011), as family firms should not be analysed as a homogeneous entity (Westhead \& Howorth, 2007). We go beyond most of the existing research that studies the difference between private and public family firms (Brune et al., 2019), private family firms and private non-family firms (Koverman \& Wendt, 2019; Monterry \& Sánchez, 2010), or public family firms and public non-family firms (Gaaya et al., 2017). It is worth noting that generational transition is one of the most sensitive processes in family firms (Miller et al., 2003; Molly et al., 2010); as such, further research is needed on this topic. Second, to examine the influence of the different controlling generations in the family firm on tax aggressiveness, we use the 2012 Spanish fiscal reform that limited the tax deductibility of interest expenses as a quasi-natural experiment (Clemente \& Sogorb, 2016; Liu et al., 2019; Overesch \& Wamser, 2010). As far as we know, this is the first empirical study to use such an approach in the family firm context. Third, we focus on SMEs for several reasons: they represent $99 \%$ of all companies in Europe and approximately two-thirds of the total turnover and employment (Molly et al., 2010) meaning they are of enormous economic importance; most SMEs are family firms are SMEs (Burgstaller \& Wagner, 2015); and family SMEs tend to be concerned with keeping family control of the company, which may result in different financial decisions (Van Caneghem \& Van Campenhout, 2012) and different tax policies (Bjuggren \& Sund, 2002). Fourth, the implications of our findings could be extended to the European framework since Spain is among the socalled high tax alignment countries (where financial statements are used as the reference for taxation, meaning there is a strong relationship between financial and tax reporting) such as Belgium, Finland and France (Van Tendeloo \& Vanstraelen, 2008). Additionally, the existing literature on tax aggressiveness is predominantly US based (which is a low tax alignment country) and does not necessarily translate to high tax alignment countries such as Spain (Steijvers \& Niskanen, 2014).

The rest of this article proceeds as follows. In the next section, we discuss the existing literature and develop the hypotheses. We then present the tax context for our research. The 'Data and Variables' section sets out the data used in this research, while the 'Methodology' section explains the main model and methodology applied. The 'Empirical results' section presents our results together with robustness tests, and the 'Discussion and Conclusion' section highlights the main conclusions and implications.

\section{Theoretical Framework and Hypotheses}

Tax aggressiveness can be understood as tax management aimed at reducing taxable income through tax planning decisions (Koverman \& Wendt, 2019). This management yields the benefit of a tax saving or lower tax payment. However, opting for tax aggressiveness is a risky decision for the firm (Amstrong et al., 2015) involving important costs (Rego \& Wilson, 2012; Stiglitz, 1985). The management of this tax planning is complex and thus needs time (Steijvers \& Niskanen, 2014), which could be a potential opportunity cost. Due to said complexity, tax aggressiveness may increase future transaction costs (Klein \& Leffler, 1981), such as the cost of hiring external experts in this area (Sholes et al., 2009). It could also lead to future penalties from fiscal authorities and may imply a price discount on firm shares (Steijvers \& Niskanen, 2014). Finally, firm and family reputation could also be affected (Hanlon \& Heitzman, 2010), and shareholders may perceive tax aggressiveness as a signal of dishonesty (Hanlon \& Slemrod, 2009).

Founder and descendants contribute actively in the governance and management of the family firm company, with generational transfer being a key concern (Basu et al., 2009). The effects of the generation in control are one of the main sources of heterogeneity in family firms (Sciascia et al., 2014), since goals in family firms are likely to change with the shift in the controlling generation (Michiels \& Molly, 2017) thus influencing managerial decisions (Cruz \& Nordqvist, 2012).

Agency theory (Jensen \& Meckling, 1976) has been the classical approach used to study tax aggressiveness in the family firm context, but the literature shows contradictory results. Whereas there is empirical evidence of a negative relationship between family firms and tax avoidance (Landry et al., 2013), because the family firm owner weighs costs over benefits thus engaging in less tax avoidance, there is also evidence showing the opposite (Kalm, Gómez-Mejía, 2016). In line with some authors who highlight the potential narrowness of agency theory (Brune et al., 2019; Sánchez et al., 2016; Steijvers \& Niskanen, 2014), we seek broader explanations for the effect of the family generation on tax aggressiveness.

The concept of socioemotional wealth (SEW) represents the non-economic parameters in the family firm decision-making process (Gómez-Mejía et al., 2007). Family firms generally seek to preserve family values over a longterm horizon, where the family firm's continuance over future generations (Steijvers \& Niskanen, 2014) and its reputation (Gedajlovic \& Carney, 2010) are the main concerns, even at the expense of financial goals (Gallo et al., 2004; Mishra \& McConaughy, 1999), such as reducing its tax li- 
ability. The preservation of the family's SEW could help to explain why family firms' behaviour may be different (Stockmanset al., 2010). We postulate that there are several ways in which the commitment to preserving SEW and its evolution over generations may weigh differently the benefits and risks of tax avoidance in family firms.

First, having a long-term framework and the desire to maintain the firm for future generations maintaining future generations are determinants of SEW (Berrone et al., 2012). The founder's concern with keeping control of the firm (Ferramosca \& Ghio, 2018) may mean that he/she is more risk-adverse and shows more conservative behaviour than his/her successors (Cabrera-Suárez et al., 2001; González, Guzmán et al., 2013). Despite the short-term benefits of tax aggressiveness, family firm founders may be reluctant to accept its potential costs, since they could negatively affect the SEW. Specifically, there is a clear connection between a firm's concern about its reputation and tax aggressiveness (Hanlon \& Slemrod, 2009; Gallemore et al., 2014), which is particularly important in the context of family SMEs (Sánchez et al., 2016). In addition, in their early stages, family SMEs may not have the knowledge and experience to engage in tax aggressive policies (Steijvers \& Niskanen, 2014), which is especially relevant because family SMEs usually lack a strategic attitude (Zehrer \& Haslwanter, 2010). As a consequence, family founders may rule out tax aggressive policies because of the adverse effect on their SEW.

Second, the heterogeneity of family SMEs reflected in family generations may result in different attitudes to tax avoidance (Chua et al., 2012). Subsequent generations coming after the founder are less likely to be influenced by socioemotional issues, with financial factors becoming more relevant (Schulze et al., 2003b; Chen et al., 2010; Sciascia et al., 2014). As the family firm passes down through successive generations, the influence of SEW decreases (GómezMejía et al., 2007), thus the controlling family's motivations become more balanced between family and business goals (Steijvers \& Niskanen, 2014). In this line, another factor explaining a possible positive relationship between generations beyond the founder and tax aggressiveness is the growing concern about dividends (Molly et al., 2010) due to the presence of a larger number of shareholders in the following generations and less pressure from financial markets (Kovermann \& Wendt, 2019). This makes tax savings more appealing (Koverman \& Wendt, 2019). Thus, in contrast to the founder, successive generations may tend more towards tax aggressiveness. Another influential factor in family SMEs' tax policies is management professionalization. As successive generations are more experienced, setting tax policy becomes a central activity, requiring the allocation of time and resources (Carlock \& Ward, 2001; Duran et al.,
2016; Sánchez et al., 2016).

In view of the two abovementioned examples of contrasting behaviour shown by founder and descendant, we propose the following hypothesis:

H1. The generation in control of the family SME has a positive relationship with tax aggressiveness. As control of the family SME passes down through the different generations, the leverage ratio decreases.

The first hypothesis does not necessary imply that first and second generation are tax aggressive, but less than subsequent generations, which result in all generations being tax aggressive but at different levels. To clarify the specific tax attitude of the different generations, we need to formulate the additional hypotheses.

In spite of Hypothesis 1, the level of tax aggressiveness does not remain steady over the different generations in family SMEs (Molly et al., 2010). The concept of "generational shadow" was first introduced by Davis and Harveston $(1988,1999)$ and relates to the influence of the founder on the subsequent generations, which results in an incomplete succession. This effect is especially evident in the transition from the founder to the second generation, meaning that conservative management behaviour will prevail in second generation family firms (Molly et al, 2010) even though they may be expected to evolve towards a more aggressive stage. On the contrary, third and later generations show a clear risk appetite (Schulze et al., 2003b) due to the higher dispersion of ownership and the fact that concerns about reputation and the preservation of SEW are on a level with concerns with economic goals (Steijvers \& Niskanen, 2014). So, from the third generation onwards, tax aggressiveness is clearly present. Consistent with the above, we hypothesize the following:

H2a. In the second generation, tax aggressiveness is similar to that of the founders (conservative). The second generation will show a similar debt response to the founder.

H2b: The third and subsequent generations show clear tax aggressiveness, strongly decreasing their leverage ratio.

\section{Tax Setting}

Under Spanish corporate taxation laws, (corporate taxation is regulated by the Consolidated Text of the Corporate Income Tax Law, Legislative Royal Decree 4/2004 of $5^{\text {th }}$ March, and in the Corporate Income Tax Regulation, Royal Decree 1777/2004 of $30^{\text {th }}$ July), corporate taxes are calculated as the statutory tax rate times the corporate taxable 
income, which in turn is determined by revenues in the tax period minus expenses in the same period. Traditionally, interest payments have been treated as expenses from a fiscal point of view, and thus considered deductible.

This tax bias in favour of the use of financial debt may affect the indebtedness level in some companies. In the OECD context, (two alternative reforms implemented in OECD countries are ACE - Allowance for Corporate Equity, which allows companies to deduct a return on equity as well as interest expenses, and CBIT - Comprehensive Business Income Tax, which fully eliminates interest deductibility), most countries have implemented policies in order to address the potential debt bias, setting limits on the deductibility of interest expenses (OECD, 2013; OECD, 2015) through the implementation of the so-called thin capitalization rule. One of the most widespread approaches is to limit tax deductibility if net interest expenses exceed a specific fraction of EBITDA (earnings before interest, taxes, depreciation and amortization). The ultimate aim of such policies is to reduce the existing debt bias, thereby decreasing the use of financial debt. This effect of thin capitalization rules is reported in the empirical literature (Buettner et al., 2012; Clemente \& Sogorb, 2016; Haufler \& Runker, 2012; Hong \& Smart, 2010; Mardan, 2017; Overesch \& Wamser, 2010; Sorensen, 2017; Wamser, 2014).

In 2012, the Spanish Government introduced a modification to the deductibility of financial expenses (Royal Decree-Law 12/2012 of $30^{\text {th }}$ March, and Resolution $16^{\text {th }}$ July 16/2012, of the General Directorate of Taxes, in relation to the limitation on the deductibility of financial expenses in the Corporation Tax) with effect from 1st January 2012. From that date on, all net interest expenses (interest expenses in excess of financial income) that exceed $30 \%$ of the company's annual operating profits, (namely, EBITDA) are not deductible for corporate tax purposes. Nevertheless, the first million Euros of net interest expenses are deductible. Accordingly, net interest expenses below or equal to 1 million Euros are tax deductible regardless of the company's operating profits in any year. This measure indirectly favours business capitalization and corresponds to the current tax treatment of financial expenses on the international stage.

With the thin capitalization rule, the tax base increases and then not all the interest expenses can be deducted for fiscal purposes (Mardan, 2017). So, affected companies, with a tax aggressive attitude, will lower their leverage ratios to optimize the tax bill and maximize the performance (Moore et al., 2017). Accordingly, they will adapt the leverage ratio to the new deductibility limit imposed by the thin capitalization rule.

\section{Method}

\section{Data and Variables}

\section{Databases}

The database used in this research comes from a primary study on the Spanish tourism industry. The economic activities considered to fall within the scope of tourism are those established by the Institute of Tourism Studies (Instituto de Estudios Turísticos, 2009) in the Active Population Survey (Encuesta de Población Activa, EPA) on employment in tourism activities. This delimitation follows the recommendations of international organizations such as the World Tourism Organization (UNWTO) and the United Nations Statistical Commission in the document Tourism Satellite Account: Methodological References (United Nations, 2000). As of 2009, the selected branches of activity correspond to those in the National Classification of Economic Activities (Clasificación Nacional de Actividades Económicas, CNAE, 2009). The sample selection was based on the universe of Spanish tourism companies listed by the Central Business Directory (Directorio Central de Empresas, DIRCE, 2009), in its 2009 update. The initial sample of 8,148 companies was selected by a stratified random procedure with allocation proportional to the representativeness of the universe by activity (considering four groups), size (taking the number of employees as a measure of the size of the company) and location. The final result of the field work, after different data cleaning processes (contacts not achieved, no activity), was 1,019 companies, representing a $95 \%$ confidence level and an error interval of $\pm 3.1 \%$. This final sample reflects a response rate of $25.6 \%$.

The data was obtained using a questionnaire which was administered in 2009 through personal interviews with the CEOs or General Managers. In order to correct the problems that tend to affect surveys as a method of obtaining data, and in order to improve the response rate and the quality of the information, a set of recommended procedures for questionnaire-based research was used, involving a modified version of the Dillman's Total Design Method (1978), which is widely accepted in the area of strategy research (Conant et al., 1990). The field work was conducted during the months of December 2009 to March 2010.

Although the family firm information refers to 2009, and only to one time period, this does not restrict our research. We only use this information to classify companies as family firms or non-family firms and to control for the generation. As the literature highlight, the ownership structure of family firm tends to be stable over time (Andrés, 2008; Miller et al., 2011; Pindado, Requejo, \& de la Torre, 
2015; Zhou, 2001).

The time trend extrapolation test suggested by Armstrong and Overton (1977) was used to check for the possible existence of non-response bias. This test is based on the comparison of the first and last respondents. It assumes that the last respondents more closely resemble the non-respondents, as they would have been non-respondents if they had not completed the second questionnaire. The results show that there are no significant differences in any of the explanatory or dependent variables.

Using this primary source, we classified the companies in the sample as either family or non-family businesses. From the total sample, 271 were non-family firms and 748 were family firms. We classify a company as a family firm if the founder and/or their descendants hold majority ownership and control the strategic decisions (Handler, 1989; Shanker \& Astrachan, 1996). With the aim of shed light on the conceptual ambiguity of the definition of family firm, Handler (1989) identified family participation in ownership as the first dimension underlying most definitions. Based on this approach, Shanker and Astracham (1996) elaborated a typology of definitions of family firm. They select the dimension ownership structure as the broader definition of family firm. This definition stands for "family firm" the one whose majority ownership and control of strategic decisions are in the hands of the founder or his/her descendants. This concept requires: (a) that there be family capital in the capital stock; (b) that the capital with the right to vote in the hands of the family is sufficient to grant it a majority political power on the board of directors. The minimum weight of the family has been set at $51 \%$ in privately held firms (criterion established by the European Group of Family Enterprises and the Board of Family Business Network) (vid. Camisón \& Monfort (eds., 2011: 59). Following Shanker and Astracham (1996), we do not refer just to the founder, but to the family capital, which has the majority political power in the capital stock.

Additionally, we incorporated data from Sistema de Análisis de Balances Ibéricos (SABI), a database managed by Bureau Van Dijk and Informa D\&B, S.A., in order to complete the financial information from 2009 to 2016. The SABI database compiles the economic-financial information annually submitted by Spanish companies in the Commercial Registry. The data on dependent and control variables were sourced from this database.

Due to the fact that SABI does not provide complete financial information for all the companies interviewed, we eventually obtained a database with 543 companies, of which 165 are non-family companies and 378 are family companies. The next step was to exclude companies with negative book equity, yielding a total of 401 companies, of which 122 are non-family companies and 279 are family companies. Then, following the European Union criteria for classifying SMEs, we applied the definitions of micro, small and medium-sized enterprises established in Commission Recommendation 2003/361/EC of $6^{\text {th }}$ May 2003, and separated the sample into the three different types. The criteria used are the following. For Micro companies: (i) Fewer than 10 employees and (ii) sales below 2 million Euros or (iii) total assets under 2 million Euros. For Small companies: (i) Fewer than 50 employees and (ii) sales below 10 million Euros or (iii) total assets under 10 million Euros. For Medium-sized companies: (i) Fewer than 250 employees and (ii) sales below 50 million Euros or (iii) total assets under 43 million Euros. The final result is shown in Table 1.

Table 1

Final number of companies

\begin{tabular}{lccccc}
\hline & Micro & Small & Medium & Large & Total \\
\hline Non-Family & 45 & 31 & 19 & 27 & 122 \\
Family & 116 & 102 & 26 & 35 & 279 \\
& & & & & \\
TOTAL & 161 & 133 & 45 & 62 & 401 \\
\hline
\end{tabular}

Source: Own elaboration.

We focus on family SMEs and more specifically on small and medium-sized companies (102 and 26, respectively, giving a total of 128 companies), due to the fact that micro companies are not likely to be affected by the 2012 thin capitalization rule, given their low volume of sales and assets and thus financial debt.

In order to mitigate the effect of outliers, all the variables are winsorized at $0.5 \%$ in each tail of the distribution. Finally, our sample contains five sub-sectors of tourist activity: accommodation, catering, intermediary, transport and complementary offer (Table 2).

Table 2

Tourist activity

\begin{tabular}{lcc}
\hline \multicolumn{1}{c}{ Variables } & Companies & Observations \\
\hline Accommodation & 69 & 552 \\
Catering & 24 & 192 \\
Intermediary & 13 & 104 \\
Transport & 11 & 88 \\
Complementary & 11 & 88 \\
Offer & & \\
$\quad$ & 128 & 1,024 \\
\hline \multicolumn{1}{c}{ TOTAL } & & \\
\hline
\end{tabular}

Source: Own elaboration 


\section{Variables}

In this Section, we describe the independent and dependent variables used in our model analysing leverage and its determinants in family firms with different controlling generations.

\section{Dependent Variable}

Leverage (LEV). Our leverage variable, LEV, is the ratio of long-term plus short-term financial debt (excluding trade credit and other non-debt liabilities) to total assets (Castro et al., 2016; Cole, 2013; López-Gracia, \& Sánchez-Andújar, 2007; Miller et al., 2007; Molly et al., 2010; Öztekin, 2015; Psillaki \& Eleftheriou, 2015; Van Caneghem \& Van Campenhout, 2010). Additionally, as a robustness check, we use an alternative leverage variable: total debt to capital employed.

The concept of "capital structure" or "financial structure" relates to financing issues. In line with the related literature (Friend \& Lang, 1988; Kassi et al., 2019; Lin et al., 2008), we exclude trade credit for several reasons. First, we focus on financial leverage given that it produces debt interest and its tax deductibility is affected by the thin capitalization rule studied in this paper (Ampenberguer et al., 2013; Clemente \& Sogorb, 2016). Second, trade credit is used for operating activities rather than financing aims (Rajan \& Zingales, 1995; Tse \& Rodgers, 2011).

The aim of the thin capitalization rule implemented in 2012 was to reduce the asymmetric treatment of equity and financial debt in corporate taxation. A lower deductibility allowance increases the tax base (Mardan, 2017). Thus, companies affected by this new rule should lower their debt ratios.

\section{Independent Variables}

Treatment (TREAT). We divide our sample into a treatment group (companies affected by the new thin capitalization rule, limiting the tax deductibility of their interest expenses) and a control group (companies not affected by it). The variable Treatment (TREAT) is equal to 1 if the company belongs to the treatment group and 0 otherwise.

In order to classify a company into the treatment group we apply the following criteria as of the year 2012 (Royal Decree-Law 12/2012, of $30^{\text {th }}$ March, which introduces various tax and administrative measures aimed at reducing the public deficit. Resolution of $16^{\text {th }}$ July 2012 , of the General Directorate of Taxes, in relation to the limitation on the deductibility of financial expenses in the Corporation Tax. Law 27/2014, of $27^{\text {th }}$ November, on Corporation Tax):
- Net interest expenses above one million Euros

- Net interest expenses exceed thirty percent (30\%) of Earnings before interest, taxes, depreciation and amortization (EBITDA).

Tax Reform (REFORM). Tax Reform (REFORM) is a time period dummy variable that takes the value 1 from year 2012 on, when the thin capitalization rule entered into force, and 0 otherwise.

Generation (GEN). Generation (GEN) represents the generation which is currently in control or has more power. This variables takes values from 1 to 4 , where 1 indicates that the generation in control is the first (founders), and 4 indicates the fourth generation and beyond (Artega \& Menéndez, 2017; Chirico et al., 2011; Chirico \& Salvato, 2014 Kellermanns \& Eddleston, 2007; Le Breton et al., 2011).

\section{Control Variables}

We include the following control variables: profitability (PROF), which is the ratio of Earnings before interest and taxes, EBIT, to total assets (Keasey et al., 2015; López-Gracia, \& Sánchez-Andújar, 2007; Schmid, 2013); growth (GROWTH) is growth in total assets (Burgstaller \& Wagner, 2015; Castro et al., 2016; Molly et al., 2010), calculated as current total assets less total assets lagged by one period divided by total assets lagged by one period; size (SIZE), which is measured as the natural logarithm of sales (González \& González, 2008; López-Gracia, \& Sánchez-Andújar, 2007); tangibility (TANG) is the ratio of fixed assets to total assets (Ampenberget et al., 2013; Burgstaller \& Wagner, 2015; González et al., 2013; Öztekin, 2015); and non-debt tax shields (NDTS) is the ratio of depreciation expenses to total assets (Clemente \& Sogorb, 2016; López-Gracia, \& Sánchez-Andújar, 2007; MacKie-Mason, 1990).

\section{Descriptive Statistics}

Table 3 shows the descriptive statistics. The mean leverage is $34.8 \%$, which is in line with the average indebtedness in the tourism sector in Spain during the period analysed (Bank of Spain, 2018).. However, it is worth noting that the $75 \%$ percentile of the sample had a leverage ratio of $51.72 \%$, which indicates that these companies are likely to be affected by the limitation on the tax deductibility of financial expenses. 
Table 3

Descriptive statistics

\begin{tabular}{lccccc}
\hline Variables & Obs. & Mean & S.D. & Minimum & Maximum \\
\hline LEV & 661 & 0.34 & 0.22 & 0.00 & 0.92 \\
TREAT & 1,024 & 0.04 & 0.19 & 0 & 1 \\
REFORM & 1,024 & 0.63 & 0.48 & 0 & 1 \\
GEN & 744 & 1.80 & 0.71 & 1 & 4 \\
PROF & 899 & 0.04 & 0.08 & -0.31 & 0.55 \\
GROWTH & 880 & 0.04 & 0.21 & -0.66 & 2.40 \\
SIZE & 880 & 14.77 & 1.12 & 8.58 & 18.75 \\
TANG & 889 & 0.48 & 0.31 & 0.00 & 0.98 \\
NDTS & 886 & 0.04 & 0.04 & 0.00 & 0.26 \\
\hline SOurce: & & & & &
\end{tabular}

Source: Own elaboration.
Table 4 shows the correlation matrix. There is a positive and significant correlation between the companies' size and the likelihood of them being affected by the tax limitation. High levels of indebtedness are usually associated with firm size. The negative correlation between non-debt tax shields and the TREAT variable may be explained by the fact that companies using tax shields other than interest expenses are unlikely to use financial debt for tax purposes, and are thus less leveraged. Overall, the low levels of correlation indicates the suitability of our data.

We conduct a multicollinearity test using the Variance Inflation Factor (VIF). The low VIF values suggest that there is no collinearity among the variables of our study.

Table 4

Correlation matrix and variance inflation factors *

\begin{tabular}{lccccccccc}
\hline & LEV & TREAT & REFORM & GEN & PROF & $\begin{array}{c}\text { GROW- } \\
\text { TH }\end{array}$ & SIZE & TANG & NTDS \\
\hline LEV & 1.000 & & & & & & & & \\
TREAT & $0.16(0.00)$ & 1.000 & & & & & & & \\
REFORM & $-0.05(0.15)$ & $0.00(1.00)$ & 1.000 & & & & & & \\
GEN & $-0.03(0.43)$ & $0.08(1.11)$ & $0.00(1.00)$ & 1.000 & & & & & \\
PROF & $-0.08(0.02)$ & $-0.03(0.27)$ & $0.02(0.38)$ & $0.00(0.99)$ & 1.000 & & & & \\
GROWTH & $0.11(0.00)$ & $-0.02(0.55)$ & $0.00(0.99)$ & $-0.06(0.12)$ & $0.12(0.00)$ & 1.000 & & & \\
SIZE & $-0.03(0.38)$ & $0.28(0.00)$ & $-0.00(0.84)$ & $0.03(0.36)$ & $0.16(0.00)$ & $0.02(0.39)$ & 1.000 & & \\
TANG & $0.14(0.00)$ & $-0.09(0.00)$ & $0.00(0.91)$ & $-0.05(0.15)$ & $-0.06(0.06)$ & $-0.10(0.00)$ & $-0.23(0.00)$ & 1.000 & \\
NDTS & $-0.02(0.60)$ & $-0.15(0.00)$ & $-0.03(0.25)$ & $0.06(0.08)$ & $0.11(0.00)$ & $-0.13(0.00)$ & $-0.07(0.03)$ & $0.31(0.00)$ & 1.000 \\
VIF & & 1.23 & 1.01 & 1.03 & 1.12 & 1.06 & 1.24 & 1.22 & 1.16 \\
\hline
\end{tabular}

*Significance levels in brackets.

Source: Own elaboration.

In order to assess whether the different generations in family companies have different tax policies, in particular, different reactions to the thin capitalization rule, we estimate panel regressions for the period 2009 to 2016 with firm fixed effects as well as control variables. We use robust standard errors, based on the Huber-White sandwich variance estimator. Specifically, we estimate the following triple difference-in-differences (DID) model (Angrist \& Pischke, 2009: 243):

LEV $_{i t}=\beta_{0}+\beta_{1} \cdot$ TREATED $_{i t}+\beta_{2} \cdot$ TAXREFORM $_{i t}+\beta_{3} \cdot$ GEN $_{i t}+\beta_{4} \cdot$ TREATED $_{i t} \cdot$ TAXREFORM $_{i t} \cdot \operatorname{GEN}_{i t}+$ $+\beta_{j} \cdot$ TREATED $_{i t}$ TAXREFORM $_{i t}+\beta_{i} \cdot$ TAXREFORM $_{i j} \cdot$ GEN $_{i j}+\beta_{i} \cdot$ TREATED $_{i t} \cdot$ GEN $_{i t}+\sum^{m} \beta_{j} \cdot$ CONTROL VARIABLES $_{j i t}+\eta_{i}+\varepsilon_{i t}$ Equation (1) where the dependent, independent and control variables are as described in Section 2. $\eta_{i}$ represents the unobservable firm-specific fixed effects of the company "i", and $\varepsilon_{i t}$ is the residual term. We include time dummies to capture context-specific factors which are common to all the companies (such as macroeconomic factors), vary over time and may affect indebtedness decisions (López-Gracia, \& Sánchez-Andújar, 2007).

$\beta_{4}$ captures the effect of the fiscal reform (treatment effect) and equals the triple DID estimate (Chetty et al., 2009). It represents the DID estimation of the treatment effect, that is, whether the generation in control modifies the effect of the treatment (tax reform) on the variation in the family firm leverage ratio. Specifically, we compare the leverage ratio of family firms with different generations in 
control, across the treatment companies, before and after the fiscal reform. According to our hypothesis, we expect a negative sign, which means that the debt ratio of the treated companies becomes smaller as the generation in power moves further away from the founder or first generation.

DID is robust approach to deal with potential endogeneity problems (Abadie, 2005; Cerulli, 2015; Donald \& Lang, 2007). The technique is based on a source of exogenous variation (Roberts \& Whited, 2013); as such, DID is suitable when evaluating contexts where observations for treated (affected) and untreated (unaffected) companies are available both before and after treatment (in this case, the thin capitalization rule).

The triple DID framework allow us to examine how the successive generations in control react differently to the new law (Hoque \& Mu, 2019; Liu et al., 2019). It enables a better understanding of this effect than the traditional DID approach, which only analyses differences by time and treatment.

\section{Results}

\section{Main Results}

Before estimating Equation (1) we check the DID trend assumption using a placebo test. We want to test whether there was a parallel trend of the dependent variable between treatment and control groups before the tax reform (before the year 2012). We limit our time period to 2009-2011 and set as a placebo an artificial tax reform in the year 2011 (Almeida et al., 2011; Clemente \& Sogorb, 2016).

Table 5 shows the results from the triple DID fixed effect regression and the placebo test. The coefficients for Models I and III are from Equation (1) without control variables, whereas the coefficients for Models II and IV include control variables. Our coefficient of interest barely changes when these controls are included (Khandker et al., 2010: 191; Oosterbeek et al., 2010). Models III and IV represent our placebo test. In the estimation of the fixed effect model of Equation (1), the GEN and TREATED time-invariant variables are not identified.

Table 5

Estimation results

\begin{tabular}{|c|c|c|c|c|}
\hline Explanatory Variables & Model I & Model II & Model III & Model IV \\
\hline TAXREFORM & $-0.061(0.049)$ & $-0.044(0.046)$ & $-0.021(0.026)$ & $-0.001(0.027)$ \\
\hline TREATED*TAXREFORM & $0.375 * * *(0.096)$ & $0.398 * * *(0.147)$ & $-0.006(0.029)$ & $-0.051(0.043)$ \\
\hline TAXREFORM*GEN & $0.017(0.024)$ & $0.005(0.020)$ & $0.010(0.011)$ & $0.002(0.011)$ \\
\hline TREATED*TAXREFORM*GEN & $-0.164 * * *(0.038)$ & $-0.167 * * *(0.055)$ & $0.005(0.012)$ & $0.024(0.017)$ \\
\hline$P R O F$ & & $-0.319 * * *(0.088)$ & & $-0.375 * *(0.157)$ \\
\hline GROWTH & & $0.224 * * *(0.041)$ & & $0.067 *(0.034)$ \\
\hline SIZE & & $0.001(0.013)$ & & $-0.024(0.023)$ \\
\hline$T A N G$ & & $0.246^{* * *}(0.093)$ & & $0.018 * *(0.072)$ \\
\hline NDTS & & $-0.210(0.289)$ & & $-1.012 *(0.519)$ \\
\hline Constant & $0.360 * * *(0.008)$ & $0.228(0.213)$ & & $0.670 *(0.364)$ \\
\hline Time dummies & Yes & Yes & Yes & Yes \\
\hline Observations & 482 & 459 & 199 & 191 \\
\hline$R$-Squared (within) & 0.05 & 0.31 & 0.01 & 0.23 \\
\hline$F$-test (p-value) & $8.69(0.000)$ & $6.89(0.000)$ & $2.45(0.053)$ & $3.37(0.001)$ \\
\hline
\end{tabular}

Notes: triple DID fixed effects panel regression coefficients estimated with robust standard errors in brackets. LEV is the dependent variable, long-term plus short-term financial debt to total assets. TAXREFORM is a time period dummy that takes the value 1 from year 2012, when the thin capitalization rule entered into force. TREAT is equal to 1 if the company belongs to the treatment group and 0 otherwise. GEN takes values from 1 to 4 , where the number indicates the generation in control. PROF is the ratio of Earnings before interest and taxes, EBIT, to total assets. GROWTH is growth in total assets. SIZE is measured as the natural logarithm of sales. TANG is the ratio of fixed assets to total assets. NDTS is the ratio of depreciation expense to total assets. Year dummies included but not reported. Superscript asterisks indicate statistical significance at $0.01(* * *), 0.05(* *)$ and $0.10(*)$ levels. 
The coefficient of the interaction TREATED*TAXRE$F O R M^{*} G E N$ captures the extent to which companies in the treatment group modify their leverage ratio when they are affected by the tax reform of 2012, depending on which generation is in control. This coefficient is negative $(-0.164$ and -0.167 ) and statistically significant at the $1 \%$ level, with or without control variables. In addition, the hierarchical variable entry test (Hayes, 2018) yields the same significance as the triple interaction $(\mathrm{p}=0.003)$. This negative coefficient suggests that the leverage ratio of companies affected by the tax reform will decrease more as the generation in control moves further away from the founder. In short, later generations are likely to react more aggressively. This finding confirms our first hypothesis.

In Models III and IV the treatment effect is not statistically significant. This means that the difference in debt ratios between control and treatment groups is not significant for any generation before the tax reform of 2012. That indicates that there is a parallel trend before the year 2012 .

As a way to visually test the first hypothesis, we graph the triple interaction showing the difference in the leverage ratio for each generation before and after the fiscal reform. Figure 1 depicts how the different generations react after the fiscal reform, that is, their different tax aggressiveness. It can be seen that tax aggressiveness increases as the generation in control moves further away from the founder. Whereas the founder and second generations are not aggressive (they do not decrease the leverage ratio), the third and fourth generations are notably tax aggressive, clearly decreasing the company's leverage ratio.

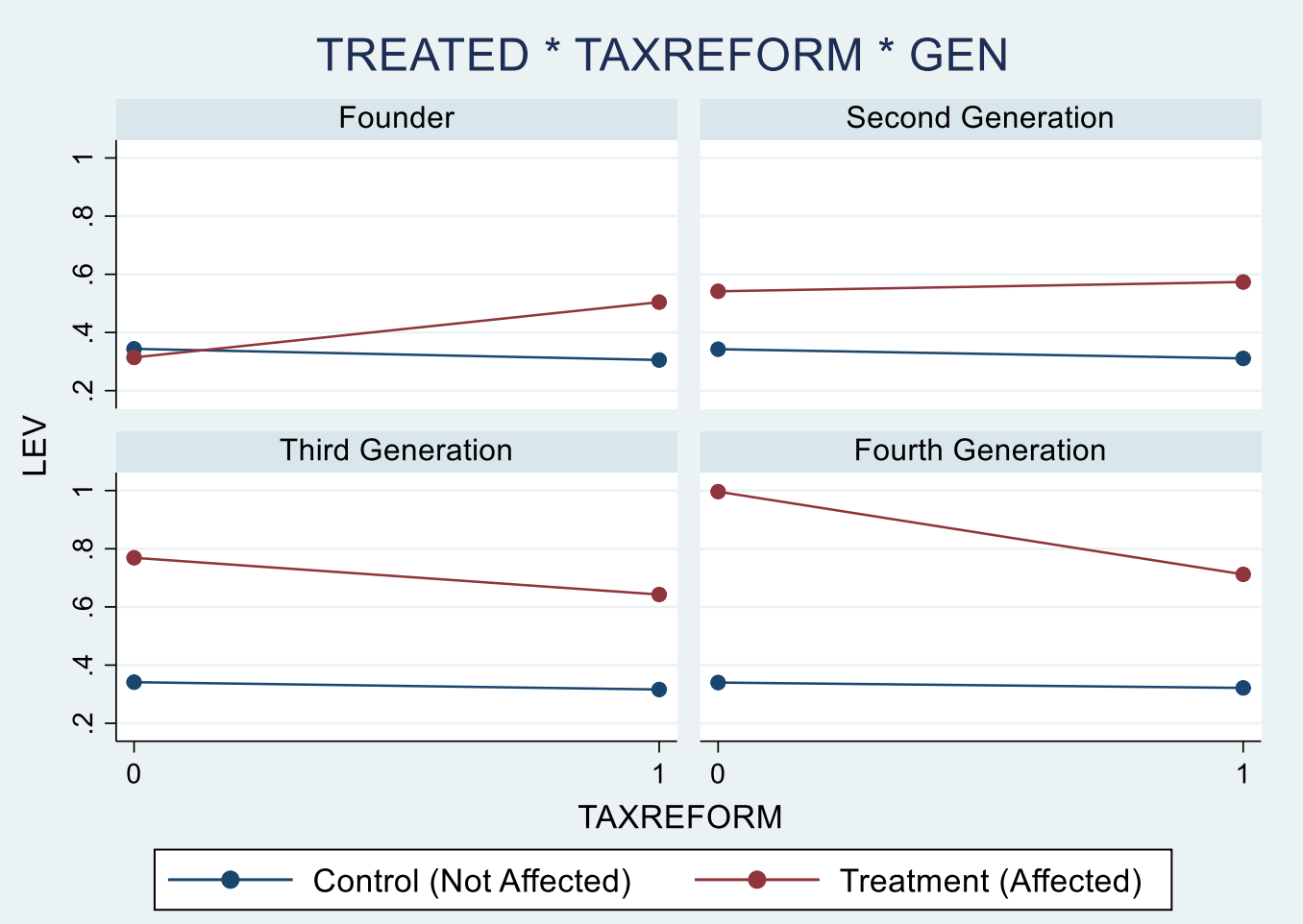

Figure 1. Treated $*$ Taxreform * Gen

In order to test the next two hypotheses, we apply the analysis of slopes (Hayes, 2018: 249). We test the effect of TAXREFORM on LEV moderated by TREATED for the four values of GEN. The p-values show that for the founder, the effect of TAXREFORM on LEV is significantly $(\mathrm{p}=0.016)$ moderated by TREATED. In other words, significantly different tax behaviour is observed for those companies affected by the reform. However, for the second generation, this effect it is clearly not significant $(\mathrm{p}=0.2433)$. Finally, the effect for the third and fourth Generations is significant ( $\mathrm{p}=0.0405$ and $\mathrm{p}=0.002$ respectively).

As can be seen in Figure 1, the tax reaction for the founder and second generation can be labelled as conservative. However, while the slope of the second generation shows conservative behaviour, as proposed in hypothesis $\mathrm{H} 2 \mathrm{a}$, it is not significant. Consequently, even though we can confirm H2a graphically, it is not confirmed statistically. Conversely, hypothesis $\mathrm{H} 2 \mathrm{~b}$ is confirmed both graphically and statistically, given the statistically significant negative slopes for the third and fourth generations. 


\section{Robustness of the Results}

In order to check our main results, we perform different robustness tests. First, we use an alternative dependent variable. Welch (2011) asserts that the traditional debt-toasset ratio is not a suitable variable for capturing changes in debt, especially when it is used in capital structure research. He argues that the total assets measure contains non-financial liabilities, which are then treated as equity. Instead Welch (2011) suggests an alternative measure that is appropriate in our research framework. The debt-to-capital employed ratio does not include non-financial liabilities (e.g. trade payables), which basically relate to operating activities rather than corporate income tax effects and capital structure issues. In Table 6 we run the same models as in Table 5, and the results are similar.

Table 6 shows the results from the triple DID fixed effect regression and the placebo test with the alternative dependent variable. The coefficients for Models I and III are from Equation (1) without control variables, whereas the coefficients for Models II and IV includes control variables. Our coefficient of interest barely changes when these controls are included (Khandker et al., 2010: 191; Oosterbeek et al., 2010). Models III and IV represent our placebo test.

Table 6

Estimation results

\begin{tabular}{lcccc}
\hline \multicolumn{1}{c}{ Explanatory Variables } & Model I & Model II & Model III & Model IV \\
\hline TAXREFORM & $-0.040(0.049)$ & $-0.217(0.050)$ & $-0.026(0.032)$ & $-0.005(0.034)$ \\
TREATED*TAXREFORM & $0.218^{* * *(0.054)}$ & $0.262 * *(0.085)$ & $0.018(0.033)$ & $-0.035(0.058)$ \\
TAXREFORM*GEN & $0.013(0.024)$ & $0.004(0.024)$ & $0.014(0.013)$ & $0.006(0.013)$ \\
TREATED*TAXREFORM*GEN & $-0.088^{* * *(0.025)}$ & $-0.101 * * *(0.024)$ & $-0.003(0.014)$ & $0.018(0.022)$ \\
PROF & & $-0.495^{* * *}(0.127)$ & & $-0.402 * *(0.190)$ \\
GROWTH & & $0.192 * * *(0.025)$ & & $0.080(0.057)$ \\
SIZE & & $0.003(0.014)$ & & $-0.049(0.039)$ \\
TANG & & $0.146(0.117)$ & & $0.153(0.101)$ \\
NDTS & & $-0.683 *(0.356)$ & & $-0.988(0.609)$ \\
Constant & $0.431^{* * *(0.009)}$ & $0.342(0.234)$ & $0.430 * * *(0.004)$ & $1.131 *(0.589)$ \\
Time dummies & Yes & Yes & Yes & Yes \\
Observations & 482 & 459 & 199 & 191 \\
$R$-Squared (within) & 0.01 & 0.23 & 0.01 & 0.23 \\
$F$-test (p-value) & $151.48(0.000)$ & $8.15(0.000)$ & $3.66(0.008)$ & $2.27(0.022)$ \\
\hline
\end{tabular}

Notes: triple DID fixed effects panel regression coefficients estimated with robust standard errors in brackets. LEV is the dependent variable, debt-to-capital employed ratio (Welch, 2011) (long-term plus short-term financial debt divided by the sum of long-term plus short-term financial debt and book value of equity). TAXREFORM is a time period dummy that takes the value 1 from year 2012, when the thin capitalization rule entered into force. TREAT is equal to 1 if the company belongs to the treatment group and 0 otherwise. GEN takes values from 1 to 4 , where the number indicates that generation in control. PROF is the ratio of Earnings before interest and taxes, EBIT, to total assets. GROWTH is growth in total assets. SIZE is measured as the natural logarithm of sales. TANG is the ratio of fixed assets to total assets. NDTS is the ratio of depreciation expense to total assets. Year dummies included but not reported. Superscript asterisks indicate statistical significance at $0.01(* *), 0.05(* *)$ and $0.10\left(^{*}\right)$ levels.

Second, we employ an alternative empirical strategy based on propensity score matching DID (PSM-DID) (Khandker et al., 2010: 198; Lins et al., 2013). Using this approach, we can examine the assumption that, if there had been no fiscal reform, the average leverage ratio for treated and control companies would have followed parallel trends. This strategy allows us to deal with the potential endog- eneity regarding time-invariant unobserved effects and to strengthen the parallel path assumptions, thus controlling for time-variant pre-treatment observables. We use the nearest neighbour approach, taking the control variables from Equation (1) as covariates in the matching process. First, we estimate a propensity score model with the initial data to make sure the comparison group is similar to the treat- 
ment group. Second, we estimate triple DID in the matched sample. So, we first conduct nearest-neighbour PSM with replacement, where we match each treated company with its 4 nearest neighbours (we also conducted nearest-neighbour PSM with 1, 2, 3 and 5 matches, obtaining the same results in Table 7 and in Table 8), that is, firms in the con- trol group with the closest propensity score (Lemmon \& Roberts, 2010; Liu et al., 2019). Table 7 exhibits the mean values of treated and control companies in both the original and matched sample, with a t-test on the differences in the mean values between the two groups. The results show that PSM successfully balances the covariates (Almeida et al., 2011; Chang \& Shim, 2015; Neckebrouck et al., 2018).

Table 7

Estimation results

\begin{tabular}{lcccc}
\hline \multicolumn{1}{c}{ Explanatory Variables } & Model I & Model II & $\begin{array}{c}\text { t-test } \\
\text { p-value }\end{array}$ \\
\hline PROF & Unmatched & 0.013 & 0.039 & 0.253 \\
& Matched & 0.013 & 0.013 & 0.983 \\
GROWTH & Unmatched & 0.042 & 0.039 & 0.969 \\
& Matched & 0.042 & 0.043 & 0.989 \\
SIZE & Unmatched & 16.333 & 14.724 & 0.000 \\
& Matched & 16.409 & 16.167 & 0.526 \\
TANG & Unmatched & 0.014 & 0.046 & 0.001 \\
& Matched & 0.012 & 0.009 & 0.376 \\
\hline
\end{tabular}

Notes: mean values of treated and control companies in both original and matched samples, with a t-test on the differences in the mean value between the two groups. PROF is the ratio of Earnings before interest and taxes, EBIT, to total assets. GROWTH is growth in total assets. SIZE is measured as the natural logarithm of sales. TANG is the ratio of fixed assets to total assets. NDTS is the ratio of depreciation expense to total assets. Year dummies included but not reported. Superscript asterisks indicate statistical significance at $0.01(* * *), 0.05(* *)$ and $0.10(*)$ levels.

We then run our triple DID fixed effect regression again, using the PSM matched sample. Table 8 shows the results of using the two alternative dependent variables (long-term plus short-term financial debt to total assets and debt-to-capital employed ratio), reporting similar values. As can be seen, the number of matched observations is smaller than the original (Liu et al., 2019).

Finally, the results from Table 5 hold when we use alternative control ariables such as the ration of EBIT to Total Assets for the PROF variable, growth in Sales for the GROWTH variable, and log of Total Assets for the SIZE variable.

\section{Discussion and Conclusion}

We analyse tax avoidance in family firms from the perspective of the generation in charge of the company. Research on tax aggressiveness has attracted a great deal of attention recently. However, despite some interesting empirical evidence (Deai \& Dharmapala, 2006), the results are contradictory on this issue. The main approach adopted has been to distinguish between public and private family firms (Mills \& Newberry, 2001), large and small fam- ily firms, or simply between family and non-family firms (Chen et al., 2010). Nonetheless, only a limited number of studies have been conducted on SMEs, with very few taking into account the heterogeneity in family firms (Chua et al., 2012). In light of this, the present paper examines the effect of different family generations on tax avoidance in a sample of family SMEs in the tourism industry, taking advantage of the unique opportunity of the quasi-experiment that the 2012 Spanish thin capitalization rule represents. Our results provide empirical evidence on family firm heterogeneity and its effect on corporate management, more specifically in regard to tax management decisions. The different motivations and goals of successive family generations influence the tax aggressiveness of the family firm.

Agency theory has been used to probe that family firm ownership structure influences tax aggressiveness. In the light of this theory, family firms are more risk averse than non-family firms, resulting in a lower tax aggressiveness (Desai \& Dharmapala, 2006). They argue that family firms are more concerned about costs of tax aggressiveness (Chen et al., 2010). However, the contradictory results found in the literature show that agency theory may fail when explaining tax aggressiveness in family firms, especially in 
Table 8

Estimation results

\begin{tabular}{lcccc}
\hline \multicolumn{1}{c}{ Explanatory Variables } & Model I & Model II & Model III & Model IV \\
\hline TAXREFORM & $-0.055(0.051)$ & $-0.056(0.045)$ & $-0.036(0.051)$ & $-0.035(0.050)$ \\
TREATED*TAXREFORM & $0.350^{* * *}(0.118)$ & $0.401^{* * *}(0.147)$ & $0.198^{* * *}(0.058)$ & $0.265^{* * *}(0.085)$ \\
TAXREFORM*GEN & $0.014(0.025)$ & $0.009(0.020)$ & $0.012(0.026)$ & $0.007(0.024)$ \\
TREATED*TAXREFORM*GEN & $-0.157^{* * *}(0.046)$ & $-0.169^{* * *}(0.055)$ & $-0.083^{* * *(0.027)}$ & $-0.103 * * *(0.035)$ \\
PROF & & $-0.259^{* * *}(0.077)$ & & $-0.428^{* * *}(0.120)$ \\
GROWTH & & $0.219 * * *(0.042)$ & & $0.186^{* * *}(0.026)$ \\
SIZE & & $0.002(0.013)$ & $0.005(0.014)$ \\
TANG & & $0.220 * *(0.098)$ & & $0.116(0.124)$ \\
NDTS & & $-0.337(0.257)$ & & $-0.830 * *(0.331)$ \\
Constant & & $0.221(0.217)$ & & $0.335(0.238)$ \\
Time dummies & Yes & Yes & Yes & Yes \\
Observations & 456 & 444 & 456 & 444 \\
-Squared (within) & 0.04 & 0.31 & 0.01 & 0.22 \\
F-test (p-value) & $6.01(0.000)$ & $6.23(0.000)$ & $17.04(0.000)$ & $7.24(0.000)$ \\
\hline
\end{tabular}

Notes: triple DID fixed effects panel regression coefficients estimated with robust standard errors in brackets using PSM matched sample. LEV is the dependent variable. In Models I \& II, LEV is long-term plus short-term financial debt to total assets. In Models III / IV, LEV is debt-to-capital employed ratio (Welch, 2011) (long-term plus short-term financial debt divided by the sum of long-term plus short-term financial debt and book value of equity). TAXREFORM is a time period dummy that takes the value 1 from year 2012, when the thin capitalization rule entered into force. TREAT is equal to 1 if the company belongs to the treatment group and 0 otherwise. GEN takes values from 1 to 4 , where the number indicates the generation in control. PROF is the ratio of Earnings before interest and taxes, EBIT, to total assets. GROWTH is growth in total assets. SIZE is measured as the natural logarithm of sales. TANG is the ratio of fixed assets to total assets. NDTS is the ratio of depreciation expense to total assets. Year dummies included but not reported. Superscript asterisks indicate statistical significance at $0.01(* * *), 0.05(* *)$ and $0.10(*)$ levels.

family SMEs. Apart from Agency theory based on family's risk perspective, further research from other perspectives (Sánchez et al., 2016). For instance, explaining unique motivations from different family generations and its relationship with family tax aggressiveness needs new approaches. As can be seen in Figure 1, as the number of generations involved in the firm increases, their specific tax behaviour changes. Third and subsequent generations include economic concerns in their decisions (Steijvers \& Niskanen, 2014), show a clear risk appetite (Schulze et al., 2003b) and are more experienced (Sánchez et al., 2016). Family founders' risk perception, which is based on agency theory, cannot explain this different behaviour. The specific existing motivations of both generation in charge (non-financial and financial goals) and family SMEs (higher ownership concentration, lower experience, and higher concern about family values - Cabrera-Suárez et al., 2014) may result in different tax policies (Bjuggren \& Sund, 2005).

Using a triple differences-in-differences method with fixed effects, we show that the leverage ratio decreases as the firm passes down through subsequent generations. As can be seen in Figure 1, the first generation shows conservative tax management, a finding which is statistically significant. The founder's desire to maintain SEW is reflected in his/her concern about keeping family control and passing the company on to his/her descendants. As a result, the founder's attitude towards risk can be considered as conservative, attributing more weight to the potential cost of tax aggressiveness, such as a negative impact on reputation, than on the tax savings.

The second generation also displays conservative tax behaviour, as shown in Figure 1. The so-called "founder's shadow" exerts an influence on the second generation, fostering the same conservative attitude (Molly et al., 2010). Although Figure 1 graphically depicts that influence, the results are not statistically significant.

The increasing importance of financial issues, a higher number of shareholders and more accumulated experience 
in the third and subsequent generations lessens the relevance of socioemotional issues. Since economic considerations are increasingly incorporated into the decision-making process, these generations present a significant positive attitude towards tax aggressiveness in view of its economic benefits.

The tourist industry differs from other industries in terms of competitiveness, leverage and risk, and these differences affect corporate decisions (Singal, 2015). Tourist industry is more competitive than other industries because, among others, high fixed cost, low flexibility, and high exit barriers. In that context, a lower cost of financing represents an improvement in the competitiveness (Chen et al., 2009). Additionally, as this industry have higher capital intensity, tourist firms usually show have leverage ratios, which is accompanied by a higher risk of financial bankruptcy. So, in the context of tourist industry, optimizing leverage ratio affects positively. Firstly, due to the optimization of interest payments and tax burden, the competitiveness increases. Secondly, a lower leverage ratio reduces the perceived risk. Both factors are critical in a highly competitive and indebted sector. Due to the sensitivity of tourist industry to competitiveness and indebtedness, this paper demonstrates that, in family firms, that the generation in control and tax aggressiveness has a relationship (positive). When the SEW prevails, even though the abovementioned industry sensitivity to performance optimization and lowering debt and risk, corporate decisions in family firms tend to be led by emotional factors. However, when the SEW lowers, the importance of the structural differences of tourist industry become dominant, and then, corporate decisions take them into account.

Although not all of our hypotheses have been confirmed, our results show that tax aggressiveness in the family firm context cannot be analysed simply from a general perspective; rather the attitudes of the different shareholders, as a reflection of their different preferences and needs, should be taken into account. Family firm heterogeneity is a multifaceted issue that affects the decision-making process. Therefore, we contribute to the literature by taking into account this heterogeneity (Sánchez et al., 2016) when explaining potential tax avoidance. Moreover, we incorporate the SEW theory together with additional factors to explain the differences in tax aggressiveness. The complexity of the family firm framework cannot be explained purely by financial factors; the distinct motivations of different actors, which also vary over time, should be taken into consideration (Berrone et al., 2012). Whereas most of the literature related to tax aggressiveness focuses on the US context, there is little empirical evidence from the European Union context. Furthermore, as far as we know, this is the first time that a quasi-experiment has been used together with a triple
DID method to examine tax aggressiveness in family firms.

This research is no exception when it comes to limitations. As our study focuses on just one sector-the tourism industry - it would be interesting to check whether this behaviour exist in other industries less sensitive to competitiveness and indebtedness, of whether the direction and intensity of the generation influence behaves in the same way.

Several implications can be drawn from our research. The benefit of our findings is to highlight the importance and influence of family firm heterogeneity in the marking decision-process (Brigham et al., 2019), and in particular, in tax aggressiveness (Chen et al., 2010). Factors such as family control, family reputation have a predominant importance in the first stages of family firm evolution, and as the family evolve and subsequent generation are involved in the family firm new interests should be balanced (Zellweger \& Kammerlander, 2015). Moreover, this heterogeneity of family firms is also present in tax aggressiveness. Family SMEs deviate from large and public family firms. They represent a unique set of characteristics that also result in specific management behaviour, such as tax aggressiveness. Thus, the implication for researchers is that a more comprehensive approach is needed when it comes to studying tax aggressiveness in family firms. Simple comparisons between family and non-family firms are not enough to explain this specific behaviour. For policy makers, this study encourages them to consider the potential effects of family firm heterogeneity when making fiscal decisions, in order to design effective fiscal policies that help family firms to increase their competitiveness. Finally, as an implication for practice, the paper is relevant for family firms and family SMEs. It is necessary to consider the complexity of interests and goals in family SMEs. Managers in their strategic decisions, such as tax management, must balance the benefits of reducing tax bill and the related socioemotional side effects for the family. For that it is important to include potential risks associated to tax aggressiveness together with approaches that aim to increase company's competitiveness. In this vein, corporate governance could include the abovementioned heterogeneity when creating rules and mechanisms adapted to the existing specific needs ana motivations in family firms, in order to find a balanced business and family strategy.

\section{Acknowledgment}

This study is part of a project funded by the Ministry of Economy, Industry and Competitiveness-State Research Agency- and Feder. Reference ECO2016-76796-P and by the Chair of Enterprise and Humanism from the University of Valencia. 


\section{References}

Abadie, A. (2005). Semiparametric difference-in-differences estimators. The Review of Economic Studies, 72(1), 1-19.

Almeida, H., Campello, M., Laranjeira, B., \& Weisbenner, S. (2011). Corporate debt maturity and the real effects of the 2007 credit crisis. Critical Finance Review, 1, 3-58.

Al-Najjar, B. (2014). Corporate governance, tourism growth and firm performance: Evidence from publicly listed tourism firms in five Middle Eastern countries. Tourism Management, 42, 342-351.

Ampenberger, M., Schmid, T., Achleitner, A., \& Kaserer, C. (2013). Capital structure decisions in family firms: Empirical evidence from a bank-based economy. Review of Managerial Science, 7(3), 247-275.

Andrés, C. (2008). Large shareholders and firm performance-An empirical examination of founding-family ownership. Journal of Corporate Finance, 14(4), 431-445.

Anderson, R. C., Mansi, S. A., Reeb, D. M. (2003). Founding family ownership and the agency cost of debt. Journal of Financial Economics, 68(2), 263-285.

Andrew, W.P., Damitio, J.W., \& Schmidgall, R.S. (2007). Financial management for the hospitality industry (2nd ed.). Pearson Prentice Hall.

Angrist, J., \& Pischke, J. (2009). Mostly harmless econometrics. An empiricist's companion. Princeton University Press.

Armstrong, C. S., Blouin, J. L., Jagolinzer, A. D., \& Larcker, D. F. (2015). Corporate governance, incentives, and tax avoidance. Journal of Accounting and Economics, 60(1), 1-17.

Armstrong, J. S., \& Overton, T. S. (1977). Estimating nonresponse bias in mail surveys. Journal of Marketing Research, 14(3), 396-402.

Arteaga, R., \& Menéndez, S. (2017). Family constitution and business performance: Moderating factors. Family Business Review, 30(4), 320-338.

Bank of Spain (2018). Economic bulletin 4/2018. Analytical articles. https://www.bde.es/bde/en/secciones/ informes/analisis-economico-e-investigacion/boletin-economico/index2018.html

Basu, N., Dimitrova, L., \& Paeglis, I. (2009). Family control and dilution in mergers. Journal of Banking and Finance, 33(5), 829-841.

Bauweraerts, J., \& Vandernoot, J. (2019). An exploratory study on the influence of family CEOs on tax aggressiveness in private family firms: The moderating role of CEO gender and survival risk. Economics Bulle- tin, 39(1), 636-648.

Berrone, P., Cruz, C., \& Gómez-Mejía, L. R. (2012). Socioemotional wealth in family firms: Theoretical dimensions, assessment approaches, and agenda for future research. Family Business Review, 25(3), 258-279.

Bjuggren, P., \& Sund, L. G. (2002). A transaction cost rationale for transition of the firm within the family, Small Business Economics, Springer, 19(2), 123-133.

Brigham, K., Kammerlander, N., \& Neubaum, D. (2019). Capturing family firm heterogeneity: How taxonomies and typologies can help the field move forward. Family Business Review, 32(2), 106-130.

Brune, A., Thomsen, M., \& Watrin, C. (2019). Tax avoidance in different firm types and the role of nonfamily involvement in private family firms. Managerial and Decision Economics, 40(8), 950-970.

Buettner, T., Overesch, M., Schreiber, U., \& Wamser, G. (2012). The impact of thin-capitalization rules on the capital structure of multinational firms. Journal of Public Economics, 96(11-12), 930-938.

Burgstaller, J., \& Wagner E. (2015). How do family ownership and founder management affect capital structure decisions and adjustment of SMES?. Journal of Risk Finance, 16(1), 73-101.

Cabrera-Suárez, K., De Saá-Pérez, P., \& García-Almeida, D. (2001). The succession process from a resource and knowledge-based view of the family firm. Family Business Review, 14(1), 37-48.

Cabrera-Suárez, M. K., Déniz-Déniz, M. C. \& Martín-Santana, J. D. (2014). The setting of non-financial goals in the family firm: The influence of family climate and identification, Journal of Family Business Strategy, 5(3), 289-299.

Camisón, C., Forés, B., \& Puig-Denia, A. (2016). Return on capital in Spanish tourism businesses: A comparative analysis of family vs non-family businesses. European Journal of Management and Business Economics, 25(3), 91-110.

Camisón, C., \& Monfort, V. (2011). La empresa turística familiar en España: Importancia, perfil y competitividad. Ministerio de Industria, Energía y Turismo, Instituto de Estudios Turísticos.

Carcello, J. V., Hermanson, D. R., Neal, T. L., \& Riley, Jr., R. A. (2002). Board characteristics and audit fees. Contemporary Accounting Research, 19(3), 365-384.

Carlock, R., \& Ward, J. (2001). Strategic planning for the family business. Parallel planning to unify the family and business. Palgrave.

Castro, P., Tascón, M. T., Amor, B., \& de Miguel, A. (2016). Target leverage and speed of adjustment along the 
life cycle of European listed firms. Business Research Quarterly, 19(3), 188-205.

Cerulli, G. (2015). Econometric evaluation of socio-economic programs. Theory and application. Springer.

Chang, S. J., \& Shim, J. (2015). When does transitioning from family to professional management improve firm performance? Transition from family to professional management. Strategic Management Journal, 36(9), 1297-1316.

Chen, M. H., Kim,W. G., \& Kim, H. J. (2005). The impact of macroeconomic and non-macroeconomic forces on hotel stock returns. International Journal of Hospitality Management, 24(2), 243-258.

Chen, M. H., Kim, W. G., \& Liao, C. N. (2009). The impact of government weekend policy changes and foreign institutional holdings on weekly effect of tourism stock performance. Journal of Hospitality and Tourism Research, 33(2), 139-160.

Chen, S., Chen, X., Cheng, Q., \& Shevlin, T. (2010). Are family firms more tax aggressive than non-family firms? Journal of Financial Economics, 95(1), 41-61.

Chetty, R., Looney, A., \& Kroft, K. (2009). Salience and taxation: Theory and evidence. American Economic Review, 99(4), 1145-1177.

Chirico, F., \& Salvato, C. (2014). Knowledge internalization and product development in family firms: When relational and affective factors matter. Entrepreneurship Theory and Practice, 40(1), 201-229.

Chirico, F., Sirmon, D., Sciascia, S. \& Mazzola, P. (2011). Resource orchestration in family firms: Investigating how entrepreneurial orientation, generational involvement, and participative strategy affect performance. Strategic Entrepreneurship Journal, 5(4), 307-326.

Chua, J. H., Chrisman, J. J., Steier, L. P. \& Rau, S. B. (2012). Sources of heterogeneity in family firms: An introduction. Entrepreneurship Theory and Practice, 36(6), 1103-1113.

Clasificación Nacional de Actividades Económicas, CNAE (2009). ht t p s: // w w w. in e.es/dyng s/I N Ebase/es/operacion.htm? c = Estadistica_C\&cid $=1254736177032 \&$ menu $=u 1 t i D a-$ tos\&idp $=1254735976614$

Clemente, J. A., \& Sogorb, F. (2016). The effect of taxes on the debt policy of Spanish listed companies. SERIEs, 7(3), 359-391.

Cole, R., (2013). What do we know about the capital structure of privately held US firms? Evidence from the surveys of small business finance. Financial Management, 42(4), 777-813.
Conant, J. S., Mokwa, M. P., \& Varadarajan, P. R. (1990). Strategic types, distinctive marketing competencies and organizational performance: A multiple measures-based study. Strategic management journal, 11(5), 365-383.

Correia, S., \& Kastenholz, E. (2011). Corporate reputation, satisfaction, delight, and loyalty towards rural lodging units in Portugal. International Journal of Hospitality Management, 30(3), 575-583.

Cruz, C., \& Nordqvist, M. (2012). Entrepreneurial orientation in family firms: A generational perspective, Small Business Economics, 38(1), 33-49.

Davis, P. S., \& Harveston, P. D. (1998). The influence of the family on the family business succession process: A multigenerational perspective. Entrepreneurship Theory and Practice, 22(3), 31-53.

Davis, P. S., \& Harveston, P. D. (1999). In the founder's shadow: Conflict in the family firm. Family Business Review, 12(4), 311-323.

Desai, M., \& Dharmapala, D. (2006). Corporate tax avoidance and high-powered incentives. Journal of Financial Economics, 84(1), 591-623.

Desai M. A., Dharmapala D. (2008) Tax and corporate governance: An economic approach. In Schön W. (Ed.), Tax and corporate governance. MPI studies on intellectual property, competition and tax law, (Vol 3)(pp. 13-30). Springer. https://doi. org/10.1007/978-3-540-77276-7_3

Dillman, D. A. (1978). Mail and telephone surveys: The total design method. Wiley.

Directorio Central de Empresas, DIRCE (2009). https:// www.ine.es/dynt3/inebase/es/index.htm?pa$\mathrm{dre}=51 \& \mathrm{dh}=1$

Donald, S., \& Lang, K. (2007). Inference with difference-in-differences and other panel data. Review of Economics and Statistics, 89(2), 221-233.

Dourado, A., \& de la Feria, R. (2008). Thin Capitalizaiton and outbound investment: Thin capitalization rules in the context of the CCCTB. In M. Lang, P. Pistone, J. Schuch, \& C. Staringer (Eds.), Common Consolidated Corporate Tax Base, (Vol. 53), (pp. 785-820). Linde.

Duran, P., Kammerlander, N., Van Essen, M. \& Zellweger, T. (2016). Doing more with less: Innovation input and output in family firms, Academy of Management Journal, 59(4), 1224-1264.

Fama, E. F. (2011). My life in finance, Annual Review of Financial Economics, 3(1), 1-15.

Feld, L. P., Heckemeyer, J. H., \& Overesch, M. (2013) Capital structure choice and company taxation: A meta-study. Journal of Bank and Finance, 37(8), 
2850-2866.

Ferramosca, S., \& Ghio, A. (2018). Accounting conservatism in family firms. In S. Ferramosca \& A. Ghio, Accounting choices in family firm, (pp. 139-164). Springer.

Frank, M., Lynch, L., \& Rego, S. (2009). Tax reporting aggressiveness and its relation to aggressive financial reporting. The Accounting Review, 84(2), 467-496.

Friend, I., \& Lang H. (1988). An empirical test of the impact of managerial self-interest con corporate capital structure. Journal of Finance, 43(2), 271-281.

Gaaya, S., Lakhal, N., \& Lakhal, F. (2017). Does family ownership reduce corporate tax avoidance? The moderating effect of audit quality. Managerial Auditing Journal, 32(7), 731-744.

Gallemore, J., Maydew, E. J., \& Thornock, J. R. (2014). The reputational costs of tax avoidance. Contemporary Accounting Research, 31(4), 1103-1133.

Gallo, M. A., Tapies, J., \& Cappuyns, K. (2004). Comparison of family and nonfamily business: Financial logic and personal preferences. Family Business Review, 17(4), 303-318.

Gedajlovic, E., \& Carney, M. (2010). Market, hierarchies and families: Toward a transaction cost theory of the family firm. Entrepreneurship Theory and Practice, 34(6), 1145-1171.

Gómez-Mejía, L. R., Haynes, K., Núñez-Nickel, M., Jacobson, K. J. L., \& Moyano-Fuentes, J. (2007). Socioemotional wealth and business risks in family-controlled firms: Evidence from Spanish olive oil mills. Administrative Science Quarterly, 52(1), 106-137.

González, M., Guzmán, A., Pombo, C., \& Trujillo, M. A. (2013). Family firms and debt: Risk aversion versus risk of losing control. Journal of Business Research, 66(11), 2308-2320.

González, V. M., \& González, F. (2008). Influence of bank concentration and institutions on capital structure: New international evidence. Journal of Corporate Finance, 14(4), 363-375.

Gouthière, B. (2005). A comparative study of the thin capitalization rules in the member states of the European Union and certain other countries. European Taxation, 45(9), 367-451.

Handler, W. C. (1989). Methodological issues and considerations in studying family businesses. Family Business Review, 2(3), 257-276.

Hanlon, M., \& Heitzman, S. (2010). A review of tax research. Journal of Accounting and Economics, 50(2-3), 127-178.

Hanlon, M., \& Slemrod, J. (2009). What does tax aggressiveness signal? Evidence from stock price reactions to news about tax shelter involvement. Journal of Public Economics, 93(1-3), 126-141.

Haufler, A., \& Runkel, M. (2012). Firms' financial choices and thin capitalization rules under corporate tax competition. European Economic Review, 56(6), $1087-1103$.

Hayes, A. (2018). Introduction to mediation, moderation, and conditional process analysis $\left(2^{\text {nd }}\right.$ ed.). Guilford.

Hong, Q., \& Smart, M. (2010). In praise of tax havens: International tax planning and foreign direct investment. European Economic Review, 54(1), 82-95.

Hoque, H., \& Mu, S. (2019). Partial private sector oversight in China's A-shape IPO market: An empirical study of the sponsorship system. Journal of Corporate Finance, 56, 17-37.

Jensen, M. C., \& Meckling, W. (1976). Theory of the firm: Managerial behavior, agency costs and ownership structure. Journal of Financial Economics, 3(4), 305-360.

Kalm, M., \& Gómez-Mejía, L. R. (2016). Socioemotional wealth preservation in family firms. Revista de Administração, 51(4), 409-411

Kassi, D., Nawadali, D., Axel, P., \& Ding, N. (2019). Market risk and financial performance of non-financial companies listed on the Moroccan Stock Exchange. Risk, 7(1), 20.

Keasey, K, Martinez, B., \& Pindado, J (2015) Young family firms: Financing decisions and the willingness to dilute control. Journal of Corporate Finance, 34, 4763.

Kellermanns, F., \& Eddleston, K. (2007). A family perspective on when conflict benefits family firm performance. Journal of Business Research, 60(10), 10481057.

Khandker, S., Koolwal, G., \& Samad, H. (2010). Handbook on impact evaluation. Quantitative methods and practices. The World Bank.

Klein, B., \& Leffler, K. B. (1981). The role of market forces in assuring contractual performance. Journal of $\mathrm{PO}^{-}$ litical Economy, 89(4), 615-641.

Kovermann, J., \& Wendt, M. (2019). Tax avoidance in family firms: Evidence from large private firms. Journal of Contemporary Accounting and Economics, 15(2), 145-157.

Landry, S., Deslandes, M., \& Fortin, A. (2013). Tax aggressiveness, corporate social responsibility, and ownership structure. Journal of Accounting, Ethics and Public Policy, 14(3), 611-645.

Lin, Y. C., Huang, S. Y., \& Young, S. C. (2008). An empirical study on the relationship between ownership and firm performance: Taiwan evidence. Afro-Asian 
Journal of Finance and Accounting, 1(1), 67-80.

Lins, K., Volpin, P., \& Wagner H. (2013). Does family control matter? International evidence from the 20082009 financial crisis. The Review of Financial Studies, 26(10), 2583-2619.

Liu, Z., Wu, H., \& Wu, J. (2019). Location-based tax incentives and entrepreneurial activities: Evidence from western regional development strategy in China. Small Business Economics, 52(3), 729-742.

López, E., Martínez, J., and García, E. (2019). Does corporate social responsibility affect tax avoidance: Evidence from family firms. Corporate Social Responsibility and Environmental Management, 26(4), 819-831.

López-Gracia, J., \& Sánchez-Andújar, S. (2007). Financial structure of the family business: Evidence from a group of small Spanish firms. Family Business Review, 20(4), 269-287.

MacKie-Mason J. K. (1990) Do taxes affect corporate financing decisions? Journal of Finance, 45(5), 14711493.

Mafrolla, E., \& D'Amico, E. (2016). Tax aggressiveness in family firms and the non-linear entrenchment effect. Journal of Family Business Strategy, 7(3), 178-184.

Manzon, G. B. \& Plesko, G. A. (2002). The relation between financial and tax reporting measures of income, Tax Law Review, 55, 175-214.

Mardan, M. (2017). Why countries differ in thin capitalization rules: The role of financial development. European Economic Review, 91, 1-14.

Mariz-Pérez, R., \& García-Álvarez, T. (2009). The internationalization strategy of Spanish indigenous franchised chains: A resource-based view. Journal of Small Business Management, 47(4), 514-530.

Mazzi, C. (2011). Family business and financial performance: Current state of knowledge and future research challenges. Journal of Family Business Strategy, 2(3), 166-181.

Michaely, R., Roberts, M. R. (2012). Corporate dividend policies: Lessons from private firms. Review of $\mathrm{Fi}^{-}$ nancial Studies, 25(3), 711-746.

Michiels, A., \& Molly, V. (2017). Financial decisions in family businesses: A review and suggestions for developing the field, Family Business Review, 30(4), 369-399.

Miller, D., \& Le Breton, I. (2006). Family governance and firm performance: Agency, stewardship and capabilities. Family Business Review, 19(1), 73-87.

Miller, D., Le Breton, I., Lester, R., \& Cannella, A. (2007). Are family firms really superior performers? Journal of Corporate Finance, 13(5), 829-858.
Miller, D., Le Breton, I., \& Lester, R. (2011). Family and lone founder ownership and strategic behaviour: Social context, identity, and institutional logics. Journal of Management Studies, 48(1), 1-25

Miller, D., Steier, L., \& Le Breton-Miller, I. (2003). Lost in time: Intergenerational succession, change, and failure in family business. Journal of Business Venturing, 18(4), 513-531.

Mills, L., \& Newberry, K. (2001). The influence of tax and non-tax costs on book-tax reporting differences: Public and private firms. Journal of American Tax Association, 23(1), 1-19.

Minnick, K., \& Noga, T. (2010). Do corporate governance characteristics influence tax management? Journal of Corporate Finance, 16(5), 703-718.

Mishra, C. S., \& McConaughy, D. L. (1999). Founding family control and capital structure: The risk of loss of control and the aversion to debt. Entrepreneurship Theory and Practice, 23(4), 53-64.

Modigliani, F., \& Miller, M. (1963) Corporate income taxes and the cost of capital: A correction. American Economic Review, 53(3), 443-53.

Molly, V., Laveren, E., \& Deloof, M. (2010). Family business succession and its impact of financial structure and performance. Family Business Review, 23(2), 131-147.

Monterry, J., \& Sánchez, A. (2010). Differences in tax aggressiveness between family and non-family companies. Spanish Journal of Finance and Accounting, 39(145), 65-97.

Moore, J., S. Suh, \& Werner, E. (2017). Dual entrenchment: Classified boards and family firms. Journal of Business Research, 79, 161-172.

Naldi, L., Cennamo, C., Corbetta, G. \& Gómez-Mejía, L. (2013). Preserving socioemotional wealth in family business: Asset or liability? The moderating role of business context. Entrepreneurship Theory and Practice, 37(6), 1341-1360.

Neckebrouck, J., Schulze. W., \& Zellweger, T. (2018). Are family firms good employers? Academy of Management Journal, 61(2), 553-585.

OECD (2013). Addressing base erosion and profit shifting. OECD.

OECD (2015). Limiting base erosion involving interest deductions and other financial payments, action 4-2015 final report. OECD.

Oosterbeek, H., van Praag, M., \& Ijsselstein, A. (2010). The impact of entrepreneurship education on entrepreneurship skills and motivation. European Economic Review, 54(3), 442-454.

Overesch, M., \& Wamser, G. (2010). Corporate tax plan- 
ning and thin capitalization rules: Evidence from a quasi-experiment. Applied Economics, 42(5), 562573.

Öztekin, Ö. (2015) Capital structure decisions around the world: Which factors are reliably important. Journal of Financial and Quantitative Analysis, 50(3), 301323.

Pindado, J., Requejo, I., \& de la Torre, C. (2015). Does family control shape corporate capital structure? An empirical analysis of Eurozone firms. Journal of Business \& Accounting, 42(7), 965-1006.

Psillaki, M., \& Eleftheriou, K. (2015). Trade credit, bank credit, and flight to quality: Evidence from French SMEs. Journal of Small Business Management, 53(4), 1219-1240.

Rajan, R., \& Zingales, L. (1995). What do we know about capital structure? Some evidence from international data. Journal of Finance, 50(5), 1421-1460.

Rego, S. O., \& Wilson, R. (2012). Equity risk incentives and corporate tax aggressiveness. Journal of Accounting Research, 50(3), 775-810.

Roberts M. R., \& Whited T. M. (2013) Endogeneity in empirical corporate finance. In G. M. Constantinides, M. Harris, \& R. M. Stulz (Eds.), Handbook of the economics of finance (Vol 2) (pp. 493-572). Elsevier.

Sánchez-Marín, G., Portillo-Navarro, M. J., \& Clavel, J. G. (2016). The influence of family involvement on tax aggressiveness of family firms. Journal of Family Business Management, 6(2), 143-168.

Shackelford, D., \& Shevlin, T. (2001). Empirical tax research in accounting. Journal of Accounting and Economics, 31(1-3), 321-387.

Shanker, M. C., \& Astrachan, J. H. (1996). Myths and realities: Family businesses' contribution to the US economy. A framework for assessing family business statistics. Family Business Review, 9(2), 107-123.

Schmid, T. (2013). Control considerations, creditor monitoring, and the capital structure of family firms. Journal of Banking \& Finance, 37(2), 257-272.

Scholes, M., Wolfson, M., Erickson, M., Maydew, E. \& Shevlin, T. (2009), Taxes and business strategy: A planning approach. Pearson Prentice Hall.

Schulze, W. S., Lubatkin, M., \& Dino, R. (2003b). Exploring the agency consequences of ownership dispersion among the directors of private family firms. Academy of Management Journal, 46(2), 179-194.

Sciascia, S., Mazzola, P., \& Kellermanns, F. W. (2014). Family management and profitability in private family-owned firms: Introducing generational stage and the socioemotional wealth perspective, Journal of Family Business Strategy, 5(2), 131-137.
Seguí, L., Clemente, J. A., Medina, R., \& Grueso, M. (2019). Sustainability and competitiveness in the tourism industry and tourist destinations: A bibliometric study. Sustainability, 11(22). https://doi.org/10.3390/ su11226351

Singal, M. (2015). How is the hospitality and tourism industry different? An empirical test of some structural characteristics. International Journal of Hospitality Management, 47, 116-119.

Sørensen, P. B. (2017). Taxation and the optimal constraint on corporate debt finance: Why a comprehensive business income tax is suboptimal. International Tax and Public Finance, 24(5), 731-753.

Stanley, L., Hernández, R., López, M., \& Kellermanns, F. (2019). A typology of family firms: An investigation of entrepreneurial orientation and performance. Family Business Review, 32(2), 174-194.

Steijvers, T., \& Niskanen, M. (2014). Tax aggressiveness in private family firms: An agency perspective, Journal of Family Business Strategy, 5(4), 335-396.

Stiglitz, J. E. (1985). The general theory of tax avoidance, National Tax Journal, 38(3), 325-337.

Stockmans, A., Lybaert, N., \& Voordeckers, W. (2010). Socioemotional wealth and earnings management in private family firms. Family Business Review, 23(3), 280-294.

Su, Y. W., \& Lin, H. L. (2014). Analysis of international tourist arrivals worldwide: The role of world heritage sites. Tourism Management, 40, 46-58.

Tse, C., \& Rodgers, T. (2011). Can corporate tax shields explain the long-term borrowing behaviour of Chinese listed firms? International Review of Financial Analysis, 20(2), 103-112.

United Nations (2000). Tourism Satellite Account: Recommended Methodological Framework. United Nations Publication.

Vacas, C., \& Landeta, M. H. (2009). Aproximación al último medio siglo de turismo en España, 1959-2009. Estudios Turísticos, 180, 21-64.

Van Caneghem, T., \& Van Campenhout, G. (2012). Quantity and quality of information and SME financial structure. Small Business Economics, 39(2), 341-358.

Van Tendeloo, B., \& Vanstraelen, A. (2008). Earnings management and audit quality in Europe: Evidence from the private client segment market. European Accounting Review, 17(3), 447-469.

Wamser, G. (2014). The impact of thin-capitalization rules on external debt usage: A propensity score matching approach. Oxford Bulletin of Economics and Statistics, 76(5), 764-781.

Welch, I. (2011). Two common problems in capital struc- 
ture research: The financial-debt-to-asset ratio and issuing activity versus leverage changes. International Review of Finance, 11(1), 1-17.

Westhead, P., \& Howorth, C. (2007). Types of private family firms: An exploratory conceptual and empirical analysis. Entrepreneurship and Regional Development, 19(5), 405-431.

Zehrer, A., \& Haslwanter, J. (2010). Management of change in Tourism: The problem of family internal succession in family tourism SMEs. Electronic Journal of Family Business Studies, 2(4), 147-162.

Zellweger, T., \& Kammerlander, N. (2015). Article commentary: Family, wealth, and governance: An agency account. Entrepreneurship Theory and Practice, 39(6), 1281-1303.

Zhou, X. (2001). Understanding the determinants of managerial ownership and the link between ownership and performance: Comment. Journal of Financial Economics, 62(3), 559-571. 